\title{
Muslim Leadership And The Threats Of Transnational Terrorism: Comparing Indonesia And Saudi Arabia
}

\author{
Badrus Sholeh \\ Department of International Relations, , Faculty of Social and Political Sciences, \\ Syarif Hidayatullah State Islamic University Jakarta \\ Badrus.sholeh@gmail.com
}

\begin{abstract}
Indonesia and Saudi Arabia are two important Muslim countries which have taken a strategic role in managing regional leadership in Southeast Asia and the Middle East respectively. They are leading regional diplomacy in maintaining stability, security, and peace. Indonesia and Saudi Arabia are two of three Muslim countries joined G20. The third country is Turkey. Both countries actively involved in constructing regional organization, democratization and preventing the rise of transnational terrorism threats. Saudi Arabia is leading country of Gulf Cooperation Council (GCC), political and economic alliances of six Gulf countries. In addition, Indonesia is significant leader in ASEAN and Asia Pacific region. Both countries are challenged by the rise of transnational terrorism threats. Great power context in this paper comes from economic posture and regional leadership in shaping security, especially combatting transnational terrorism. This paper examines the role of Indonesia and Saudi Arabia in regional leadership, and how they lead a regional cooperation on countering terrorism in each region.
\end{abstract}

Keywords - Indonesia, Saudi Arabia, Regional Leadership, Transnational Terrorism

\section{INTRODUCTION}

Regional leadership of Indonesia and Saudi Arabia have been acknowledged by some scholars. Greg Fealy and Hugh White argued the posture of the economy and stable democracy made Indonesia deserved to be a great power in Asia Pacific region by some requirement internal and external role including defense and diplomatic capability. They said "there remain very significant hurdles to be overcome before Indonesia could effectively function as a great power in the Asian strategic system. Its armed forces remain overwhelmingly focused on internal security and seem, under Jokowi, less focused on building up external capabilities" [1]. The World Bank reported that GDP of Indonesian growth increased from 4.9 in 2015 to 5.1 in 2017. It is estimated rising after President Joko Widodo's infrastructure completed by 2018. At Kearney Global Business Policy Center (2017) published Global Economic $\backslash$

Outlook 2017-2021 stated that Indonesia and Saudi Arabia will face a shock and tension affecting their economy and regional leadership due to terrorism threats in each region.

Indonesia and Saudi Arabia manage a common interest in countering terrorism from Al Qaida to the Islamic State. Al
Qaida's terrorist networks used to be their lists of terrorism threats for more than a decade from 2001 to 2012. Osamah bin Laden stated Saudi Arabia the closest ally of the U.S. in the Middle East and threatened the country by some terrorist attack operations. In addition, Indonesia shocked by series of bomb attacks by Jama'ah Islamiah, one of Southeast Asian Al Qaida's networks, from 2002, the Bali bombings. After some periods of government countering terrorism policy including deradicalization and rehabilitation, some former terrorists used to affiliate to AQ become pioneers in countering terrorism joining government efforts on combatting terrorism. This is important turning points of efforts in fighting terrorism in Indonesia and Saudi Arabia.

In 2013 however, Indonesia and Saudi Arabia found new challenge after the foundation of Islamic State of Iraq and Syria (ISIS), then called the Islamic State (IS). Radical jihadi individuals and organizations from Indonesia and Saudi Arabia declared to join (ISIS/ IS) and supported Abu Bakar alBaghdady as a Caliphate. This is a new phase of transnational terrorism after AQ's networks collapsed. This is among challenges of great power to both Saudi Arabia and Indonesia. Countering terrorism efforts by both countries are influential to regional political-security.

This article examines the challenges of countering terrorism policy in Indonesia and Saudi Arabia, and how both country manage themselves a leading role in regional leadership on shaping politics and international security. It argues Indonesia and Saudi Arabia are strategic countries in maintaining regional development, security and stability in the Asia Pacific and the Middle East.

\section{THEORETICAL DEBATES}

Syrian conflicts and new phase of transnational terrorism affected the way of Indonesia and Saudi Arabia in managing security, diplomacy and international cooperation. Quoting Mearsheimer's argument on neorealism that international regime needs to consider realism approach in overcoming transnational terrorism in the Middle East and Asia, especially to understand and to cooperate with Russia and China in fighting the Islamic State and preventing IS to threaten regional security. Mearsheimer warned the failure of Iraq and Afghan's 
policy in countering terrorism which using liberal internationalism approach.

Mearsheimer's neorealism is also relevant to understand counterterrorism policy, especially how state behaves responding the threats of IS in Asia and the Middle East. In addition, CT and CVE include security and defense policy involving Police terrorism squad to manage local and national security and Military for national defense from transnational terrorism threats. Although dialogue to terrorists and the role of former terrorist groups in CT/ CVE are among the practice of liberalism. Democracy of the Republic of Indonesia constructed strong civil society and participation of the people in managing political violence affected to the low percentage of people to join IS in Syria and Iraq. On the other hand, a high number of Saudi Arabia citizens to support IS in the Middle East questioned the success of the country on rehabilitation and deradicalization programs. It argued government policy in supporting the opposition in Syria contributed to the rise of IS as well as other Sunni militia followers originally from Saudi. Critique to Countering Terrorism also came to the issue of human rights. State' behaviour in managing CT/ CVE is argued by some scholars to abuse the state power and to violate human rights. There are two possible reasons behind the policy. Firstly, $\mathrm{CT}$ and later CVE as government policy are quite new responding the terrorist attacks series from 2001 to 2002. The government did not have enough time to discuss the policy intensively. Furthermore, terrorism is considered to threaten national security which resulted in state interests in protecting the citizens. In neo-realist principles, national interests of security provided a huge responsibility to the government in fighting against terrorism. Civil society is only a second or third group after the state failed to comprehensively counter terrorism. Narratives to balance the ideology and thought of the violent extremism need a strong participation of Muslim society. Indonesian and Saudi Arabia Muslim scholars are encouraged to join the state in prevention and countering violent extremism. However, frictions among civil society on CT/ CVE weakened the effort of government in effectively fighting terrorism.

\section{REGIONAL LEADERSHIP}

Indonesia and Saudi Arabia took a strategic position as great powers in Asia-Pacific and the Middle East respectively. Their economic posture and their leadership in shaping regional security are among signs how they are recognized as great powers.

Fealy and White (2016) considered Indonesia as a very influential country in the Asia-Pacific from varieties of perspectives. In the democratic transition of the region, Indonesia leads the others. Indonesia helped Myanmar's transition from authoritarian military to democratic civilian regimes. International efforts to embargo Myanmar were opposed by Indonesian government which took persuasive and dialogue with Myanmar. It resulted to smooth transition from military to civilian political leadership. Indonesia also took a leadership position in assisting negotiation and conflict resolution the Philippines from 1996 to 2012. Separatist movements of MNLF and MILF transformed themselves as political powers participating in local politics and development. Minority Muslims in Southeast Asia and Asia-Pacific regions expected leading roles of Indonesia. Furthermore, in countering terrorism, Indonesia contributed greatly due to the high number of individuals and groups of radical jihadism affiliated to terrorism groups from Jama'ah Islamiyah to the Islamic State.

Similar position to Indonesia, Saudi Arabia took a pivotal leadership at GCC (Gulf Cooperation Council). As the only G20 member of the GCC, Saudi Arabia has led other countries for decades. Saudi expanded its influence in the Asian region by visiting Indonesia, China, and Asian countries in March 2017. Saudi planned to invest in economic sectors including building knowledge and science technology with China. The visit of King Salman to Indonesia strengthened both countries as two great powers from Asia and the Middle East. Ambassador Agus Maftukh confirmed the visit of Salman is strategic for Indonesia [2]. This is the highest authority of Saudi Arabia,s second visit to Indonesia after about forty years. The exchanges of visit of Indonesian and Saudi Arabian leaders will strengthen their capacity to construct their roles at international level.

Saudi Arabia's visit to Asia in March 2017 showed the more progressive effort to broaden their economy to non-energy sources. Saudi built economic cooperation with the allies, the U.S. and the West, as well as China, Russia and Southeast Asia, including Indonesia. Siwage Dharma Negara stated, "Saudi Arabia's economic performance and reforms plans should be taken into account in assessing what type and level economic cooperation between the country and Indonesia is feasible" [3]. For Saudi Arabia, the 2017 visit to some Asian countries, including Indonesia, Malaysia, China, and Japan is "arguably a way for the kingdom to seek economic partners and investors to support its national transformation plan" [4].

Saudi Arabia's leadership in counterterrorism affected to the global war on terror. Some key actors of global terrorists come from Saudi Arabia and Arab regions. Daniel Byman argued, "Saudi Arabia has made considerable progress on counterterrorism in the last 15 years but still has a way to go" [5]. Counterterrorism needs a holistic policy from security to ideology. The last aspect of terrorism, the ideology of radicals, rooted from Wahabism teachings. This is how Saudi Arabia have to reform their global campaign on Wahabism. Byman continued "the Saudi Kingdom still spews out material that is anti-Semitic, sectarian, glorifies several conflicts in which jihadists play an active role, and otherwise contributes to a climate of radicalization" [6].

The further challenges for Saudi Arabia as a great power in Gulf region are first, Saudi Arabia loses its political dominance after the rise of other Gulf countries like Qatar and Uni Emirate Arab. 
Secondly, the resistance of Saudi Arabia to the rivals of neighbouring countries shows the limit of Saudi Arabia's political dominance in the region. Thirdly, the dependence of Saudi Arabia to the United States in the security sector. If Saudi Arabia continues its role in regional leadership, it has to move on without support from the U.S. King Salman's visit to Asia a few months ago by negotiating education and knowledge transfer from China to Saudi Arabia on some sectors including preparation to build nuclear weapons.

\section{CONCLUSION}

Indonesia and Saudi Arabia are important two Muslim countries, members of G-20, having a strategic role in managing human rights and security in each region. Scholars considered them as great powers in Asia Pacific and Gulf region respectively due to their economic posture and their leadership in preventing and countering transnational terrorism. Indonesia performed a procedural democracy. In addition, Saudi Arabia is very influential in GCC members, with a new challenge after frictions with Qatar and Iran.

National interests of Indonesia and Saudi Arabia in protecting national economy and security as well as less consistency of domestic politics (in Indonesian context) will reduce their leadership capacity like how Fealy and White doubted Indonesia's regional role after the New Order [7]. Frictions among national leaders will influence international diplomacy and regional leadership in constructing prosperous and peaceful region.

Counterterrorism leadership of Indonesia and Saudi Arabia in Arab peninsula and Asia Pacific respectively need a solid coordination among stakeholders in national and regional levels. The Indonesian National Counterterrorism Agency (BNPT) plan to include 32 state ministries and government body by 2018 is important to preventing and countering terrorism. ASEAN state members also confirmed to strengthen their cooperation on counterterrorism in which Indonesia took the strategic role. Like Indonesia, Saudi Arabia also continued leading the effort to fight terrorism by incorporating Gulf and Arab peninsula countries. Indonesia and Saudi Arabia are suffered by AlQaidah and the Islamic State terrorist targets. Their leadership role will strengthen their policy to counter AQ and IS, and future terrorist groups which are developing in the region.

\section{Reference}

[1] Fealy, Greg \& White, Hugh. (2016). "Indonesia's "Great Power" Aspirations: A Critical View." Special Issue, Asia \& the Pacific Policy Studies, Vol. 3, No. 1, p. 100.

[2] Maftukh, Agus. (2017). Indonesian Ambassador to Saudi Arabia, Personal Interviews, 1 August.

[3] Negara, Siwage Dharma. (2017). "The Impact of Saudi King's Visit to Indonesia." Perspective, no. 16, 10 March. ISEAS Yusof Ishak Institute, p. 6.
[4] Negara, Siwage Dharma. (2017). "The Impact of Saudi King's Visit to Indonesia," p. 6.

[5] Byman, Daniel. (2016). The U.S. - Saudi Arabia Counterterrorism Relationship. Testimony. House Committee on Foreign Affairs, Subcommittee on Terrorism, Nonproliferation, and Trade, 24 May, p. 1.

[6] Byman, Daniel. (2016). The U.S. - Saudi Arabia Counterterrorism Relationship, p. 1.

[7] Fealy, Greg \& White, Hugh. (2016). "Indonesia's "Great Power" Aspirations: A Critical View," p. 100. 